\title{
Investigation of the Perceptions of Students Who Participate in Sports Organizations in Universities Regarding the Term "Sports"
}

\author{
Fatih MURATHAN $^{1}$ \\ ${ }^{1}$ School of Management, Adiyaman University, Adiyaman, Turkey \\ Correspondence: Fatih MURATHAN, School of Physical Education and Sports, Adiyaman University, Adiyaman, \\ Turkey.
}

Received: January 1, 2019

Accepted: February 11, 2019

Online Published: March 25, 2019

doi:10.5539/ies.v12n4p236

URL: https://doi.org/10.5539/ies.v12n4p236

\begin{abstract}
The main aim of this study is to investigate the perceptions of students who participate in sports organizations in universities regarding the term "sports". With this main aim, the perception of the term was explained by metaphors. The study group includes 108 female and 112 male volunteer students, who studied in various departments of Adiyaman University during the 2017-2018 education period. For the data collection tools in the study, a short personal information form and the form that asks to complete the sentence, "Sports are like ... Because ..." In the data analysis, with the SPSS 24.00 package software, individual variables were classified and four steps were followed in the analysis of the metaphors. These steps are naming the metaphors, elimination and refinement, compilation and categorization, and the findings were obtained by validity and reliability analyses. As a result of the research, it was determined that $88.7 \%$ of the students who participated in sports organizations in universities developed positive metaphors while 11.3 developed negative metaphors. Additionally, it was concluded that these metaphors created significant differences according to students' genders, and the departments and programs of study. As a result of the study, it can be concluded that university students participating in sports activities voluntarily have a perception of "sports" as improving health, regarding as a profession and gaining social prestige and this result affects their future life positively.
\end{abstract}

Keywords: sports, metaphor, university students

\section{Introduction}

The term, metaphor, was derived from the Greek word "metapherein" (to transfer) and was formed by combining the words "meta" (in between) and "pherein" (to carry, to transport). A metaphor is to transfer of meaning from one to another (Nikitina \& Furuoka, 2008, p. 194). Although metaphors are traditionally regarded as figures that decorate the language of a speaker, psychologists and linguists recently defined it in different ways. For example, Kramsch defined metaphor as "transmitting two frequently incompatible sources to each other". Ortony and Fainsilber regarded it as "an important tool of cognition and communication" (As cited in Nikitina \& Furuoka, 2008, p. 194). These definitions render metaphors (similes, figures of speech, tropes etc.) as one of the most powerful mental tools that structure, guide and control our thought about the formation and progression of events (Saban, 2004, p. 131). Another important characteristic of metaphors is that they facilitate the cognitive process of people (Nikitina \& Furuoka, 2008, p. 194). Therefore, a metaphor draws attention as a powerful mental mapping and modeling mechanism for individuals to understand and configure their own worlds (Arslan \& Bayrakç1, 2006, p. 103).

The term, metaphor, which has various definitions in the literature, was defined by the Turkish Language Association (Web1) as "using a word or a term in a way that means something outside of what is presumed. Generally, metaphors, by providing that the individual's mind is moved from a certain way of comprehension to another way of comprehension, enable that the individual view a certain event as another event (Saban, 2008). In other words, by means of metaphors, just as in similes, the concept to be expressed is tried to be explained by another concept with a similarity (Çelikten, 2006). In this regard, metaphors cover the information transfer from a commonly known field to another unknown field (Lakoff \& Johnson, 2005). However, metaphor, whose meaning is retraced to "to transfer" in Greek (Fenwick, 2000), expresses much more than just rhetoric that decorate the language we use in everyday life (Saban, 2008; Aydın, 2010). Metaphors serve to express what is wished to be told in a more effective and stressed way (Aydın, 2010). Metaphors also draw attention as a powerful mental mapping 
and modeling mechanism for individuals to understand and configure their own worlds (Arslan \& Bayrakç1, 2006). Therefore, metaphors are regarded as powerful mental tools which can get to work in an individual's comprehension and explanation of a highly abstract, complex and theoretical phenomenon (Saban, Koçbeker \& Saban, 2006). This is because metaphors help us understand, visualize and make sense of the outer world by mental processes (Arslan \& Bayrakçı, 2006). Metaphors, with those qualities, are major linguistic devices that humankind actually discovered to understand, explain, establish and organize the world (Lakoff \& Johnson, 2005).

There are those who advocate that metaphoric thinking process is composed of two sections. One of these sections is the "subject" while the other is the "tool". The subject is the phenomenon, event or the concept that is wished to be explained. The tool is a term or terms used metaphorically (Balc1, 1999, p. 33). For example, in "Sports are my source of happiness. Because I let off all of my steam via sports", the term "sports are my source of happiness" is used as the subject while in the sentence, "I let off all of my steam via sports" is used as the tool.

According to Goldstein, metaphors can be used to promote the redefinition of realities and reconceptualization of problem situations because they affect our comprehension of situations and events (As cited in Cerit, 2008, p. 694). In this context, explaining the term, sports, via metaphors can help us to understand what it means for the students and what their expectations are in a better way.

Due to the effects it creates, the language of sports, which is an inseparable part of social reality, is one of the fields where metaphors are used frequently. Lipstye (1975) stated that the American Language of Sports, which contains many metaphors, is integrated into the national language system (Lipstye, 1975, p. 118). Palmatier and Ray (1989) determined 1700 commonly used sports metaphors as a result of investigating approximately 100 sports events in various branches. Most of these metaphors were integrated into American everyday speech thanks to sports (Palmatier \& Ray, 1989, p. 7).

Offstein and Neck (2003) reported that sports metaphors can simplify the processes of learning difficult concepts and can render communication process entertaining and they are rather valuable in education processes especially due to their ability to attract the attention of readers. Associatively, expressing terms of sports with metaphors provides strong clues into comprehending what sports mean for the society and what are the expectations of the society from sports (Koç et al., 2015). Similarly to those views, Offstein and Neck (2003) stated that using metaphors in sports has an increasing tendency and this situation not only eases the expressions thanks to metaphors but also provides opportunities to determine the general perception regarding sports (Offstein \& Neck, 2003, p. 74).

In the light of this information, in this study, it was aimed to reveal the perceptions of university students, who participate in sports organization in universities as licensed athletes, regarding the term "sports" via metaphors. In accordance with this main aim, it was attempted to determine which metaphors the study group employs to express their perception of the term "sports" and in which category the student collect these metaphors they put forward for the term "sports".

\section{Method}

\subsection{Research Model}

In this study, quantitative and qualitative research designs were used together. In the quantitative research, the descriptive method was employed, making use of frequencies. In the qualitative research, phenomenology design was used to analyze the metaphors regarding sports. Phenomenology design is a study design to investigate known yet not completely comprehended phenomena. Investigating perceptions, tendencies and concepts is suitable for this research design (Yıldırım, \& Şimşek, 2006).

\subsection{Population and Sample}

While building the study group, phenomenology technique, which is frequently employed in metaphor studies, was adopted. While forming data sources in phenomenology studies, the principle should not be forgotten that forming individuals or groups who experience the phenomenon and can express the phenomenon will ensure forming metaphors correctly (Yıldırım \& Şimşek, 2011). Concurrently, it is necessary for these groups to experience this phenomenon in all its aspects (Creswell, 2013). Therefore, in this study, licensed athletes, who experience the phenomenon, "sports", the phenomenon of this study, as the study group. 
Table 1. Gender distribution of the study group

\begin{tabular}{lcc}
\hline Gender & $\mathrm{F}$ & $\%$ \\
\hline Female & 108 & 49.90 \\
Male & 112 & 50.10 \\
Total & 220 & 100 \\
\hline
\end{tabular}

In Table 1, the gender distribution of the study group was presented. Accordingly, the study group is comprised of 108 females and 112 males. While forming the study group, homogeneity in gender distribution was taken into consideration. Adiyaman University students participated in the study voluntarily.

\subsection{Data Collection Tools}

The first section of the data collection tool, which is comprised of two sections, contains personal information and information regarding "department/program of study, sports branch and age of licensed sports". The second section contains expressions aimed at determining the metaphors of the participants regarding the term "sports."

In studies, which used metaphors as tools of research, the term "like" is used to associate the connection between the subject of the metaphor and the source of the metaphor in a clearer way (Saban, 2008). Additionally, according to Yıldırım and Şimşek (2006), because the metaphor itself is not enough to reveal the descriptive power of the metaphor, the questions of "why" should definitely be present alongside the metaphor. This is because each individual can assign a different meaning to the same metaphor. These differences assigned or the desired aim while using a metaphor can only be obtained by the answer to the question "why". Thus, in this study, the reasons for the participants' metaphors were attempted to be determined by the sentence "Because..." For example, the students were asked to complete the sentence "Sports are like ... because ...", forming metaphors regarding the term "sports".

\subsection{Data Analysis}

In the analysis of the data obtained in the study, the content analysis method was adopted. Accordingly, the analysis of the metaphors formed by the university students and the process of interpretation was conducted in four stages: $1^{\text {st }}$ Naming stage, $2^{\text {nd }}$ Elimination and refinement, $3{ }^{\text {rd }}$ Compilation and categorization, $4^{\text {th }}$ Providing validity and reliability stage

In the naming stage, a temporary list of the metaphors was formed in alphabetical order and it was investigated whether the students formed a metaphor in a clear way. In the elimination and refinement stage, the metaphors formed by students were re-evaluated and the 10 forms, which did not include a source of metaphor and an explanation, were discarded, obtaining the valid metaphors.

In the compilation and categorization stage, the metaphors formed were divided into two groups as positive and negative metaphors. Then, they were categorized into four groups in terms of the common properties they have regarding the term "sports". Sample student explanations were also included next to the metaphors formed.

In the providing validity and reliability stage, experts' opinions were asked in order to determine whether the metaphors in the four categories represented the relevant category. The experts were asked to match the categories and the list formed by the experts and the researchers were compared. As a result of the comparison, it was determined that the experts and the researcher were in agreement for 22 metaphors while for the metaphors, "eating the best fruit" and "reverse life", the experts and the researcher were in disagreement. For the reliability of the study, the formula put forward by Miles and Huberman (1994), P (Percentage of Agreement \%) $=$ $[\mathrm{Na}$ (Agreement) $/ \mathrm{Na}$ (Agreement) $+\mathrm{Nd}$ (Divergence) $\mathrm{x} 100$, was used and the reliability is provided when the ratio between the qualitative research experts and the researcher is $90 \%$ and above (Saban, 2008, p. 430). According to the formula of Miles and Huberman, the reliability of the study was calculated as 20/(20+2): 0.92 . 


\section{Results}

Table 2. Metaphors formed regarding the term "sports and the frequency and percentage of students representing those

\begin{tabular}{|c|c|c|c|c|c|c|}
\hline \multirow[b]{2}{*}{ Category } & \multirow[b]{2}{*}{ No } & \multirow[b]{2}{*}{ Code } & \multicolumn{4}{|c|}{ Students representing the metaphor } \\
\hline & & & $\mathrm{f}$ & $\%$ & $\begin{array}{c}\text { Codes } \\
(\mathrm{f})\end{array}$ & $\begin{array}{c}\text { Total } \\
(\%) \\
\end{array}$ \\
\hline \multirow{24}{*}{ Positive } & 1 & Life & 27 & 12.27 & \multirow{24}{*}{197} & \multirow{24}{*}{89.54} \\
\hline & 2 & Family & 19 & 8.63 & & \\
\hline & 3 & Profession & 18 & 8.18 & & \\
\hline & 4 & Happiness & 16 & 7.27 & & \\
\hline & 5 & Socialization & 16 & 7.27 & & \\
\hline & 6 & Freedom & 14 & 6.36 & & \\
\hline & 7 & Education & 13 & 5.90 & & \\
\hline & 8 & Entertainment & 12 & 5.45 & & \\
\hline & 9 & Friend & 8 & 3.63 & & \\
\hline & 10 & Peace & 7 & 3.18 & & \\
\hline & 11 & Health & 7 & 3.18 & & \\
\hline & 12 & Love & 6 & 2.72 & & \\
\hline & 13 & Nutrition & 5 & 2.27 & & \\
\hline & 14 & Motivation & 5 & 2.27 & & \\
\hline & 15 & Pleasure & 5 & 2.27 & & \\
\hline & 16 & Breath & 4 & 1.81 & & \\
\hline & 17 & Future & 3 & 1.36 & & \\
\hline & 18 & Self-confidence & 3 & 1.36 & & \\
\hline & 19 & Success & 2 & 0.90 & & \\
\hline & 20 & Sex & 2 & 0.90 & & \\
\hline & 21 & Therapy & 2 & 0.90 & & \\
\hline & 22 & Longing & 1 & 0.45 & & \\
\hline & 23 & Affinity & 1 & 0.45 & & \\
\hline & 24 & Water & 1 & 0.45 & & \\
\hline \multirow{5}{*}{ Negative } & 25 & Addiction & 9 & 4.09 & \multirow{5}{*}{23} & \multirow{5}{*}{10.46} \\
\hline & 26 & Stress & 6 & 2.72 & & \\
\hline & 27 & Loss of time & 5 & 2.27 & & \\
\hline & 28 & Poison & 2 & 0.90 & & \\
\hline & 29 & Darkness & 1 & 0.45 & & \\
\hline
\end{tabular}

In Table 2, the frequency and percentage values for the metaphors formed by the study group regarding the term "sports" were presented. Accordingly, it was observed that 29 different positive metaphors and 5 different negative metaphors were formed as a result of the study. While the frequency of positive metaphors covered $89.54 \%$, the frequency distribution of the negative metaphors was $10.46 \%$. According to Table 2, a majority of the athlete participants in the study formed positive metaphors regarding the term "sports", most of the metaphors being about life, family, profession, happiness and socialization. 
Table 3. Classification of the positive metaphors formed regarding the term "sports" into sub-groups and the frequency and percentage of the students representing those

\begin{tabular}{|c|c|c|c|c|c|c|c|}
\hline \multirow[t]{2}{*}{ Category } & \multirow[t]{2}{*}{ Group } & \multirow[t]{2}{*}{ Metaphor } & \multirow[t]{2}{*}{ Sample Expressions of Students } & \multicolumn{4}{|c|}{ Students representing the metaphor } \\
\hline & & & & $\mathrm{f}$ & $\%$ & $\begin{array}{c}\text { Codes } \\
\text { (f) }\end{array}$ & $\begin{array}{c}\text { Total } \\
(\%)\end{array}$ \\
\hline \multirow{7}{*}{ 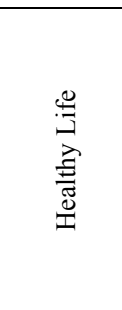 } & 1 & Life & "It is necessary in terms of healthy life" & 27 & 12.27 & \multirow{7}{*}{60} & \multirow{7}{*}{27.27} \\
\hline & 13 & Nutrition & "I gain a behavior of regular-diet via sports" & 5 & 2.27 & & \\
\hline & 11 & Health & "I feel healthy" & 7 & 3.18 & & \\
\hline & 16 & Breath & "My breathing relaxes when I exercise " & 4 & 1.81 & & \\
\hline & 7 & Education & "I learn new things every day" & 13 & 5.90 & & \\
\hline & 21 & Therapy & "I forget my troubles when I exercise" & 2 & 0.90 & & \\
\hline & 20 & Sex & "It gives both pleasure and tiredness" & 2 & 0.90 & & \\
\hline \multirow{11}{*}{ 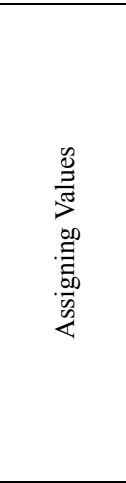 } & 2 & Family & "It is like my family. I always want it to be next to me" & 19 & 8.63 & \multirow{11}{*}{92} & \multirow{11}{*}{41.81} \\
\hline & 15 & Pleasure & "It is my largest source of pleasure" & 5 & 2.27 & & \\
\hline & 3 & Profession & "I earn my keep via sports" & 18 & 8.18 & & \\
\hline & 4 & Happiness & "It is my source of happiness" & 16 & 7.27 & & \\
\hline & 8 & Entertainment & "I enjoy sports" & 12 & 5.45 & & \\
\hline & 10 & Peace & "I forget my troubles with sports" & 7 & 3.18 & & \\
\hline & 12 & Love & "It hurts you but you cannot give up" & 6 & 2.72 & & \\
\hline & 17 & Future & "Sports is my future" & 3 & 1.36 & & \\
\hline & 18 & Self-confidence & "I feel respectable via sports" & 3 & 1.36 & & \\
\hline & 19 & Success & "The more you exercise the more successful you become" & 2 & 0.90 & & \\
\hline & 24 & Water & "It gives life like water" & 1 & 0.45 & & \\
\hline \multirow{7}{*}{ 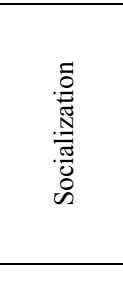 } & 5 & Socialization & "I get to know new places and new people" & 16 & 7.27 & \multirow{6}{*}{45} & \multirow{6}{*}{20.45} \\
\hline & 6 & Freedom & "I become free via sports" & 14 & 6.36 & & \\
\hline & 9 & Friend & "I establish new friendships" & 8 & 3.63 & & \\
\hline & 14 & Motivation & "I feel powerful as I exercise" & 5 & 2.27 & & \\
\hline & 22 & Longing & "It is indispensable for my life." & 1 & 0.45 & & \\
\hline & 23 & Affinity & "I believe I will find the spouse of my life via sports." & 1 & 0.45 & & \\
\hline & & & TOTAL & 197 & 89.54 & 197 & 89.54 \\
\hline
\end{tabular}

In Table 3, the frequency distribution and the sub-groups of the positive metaphors of the study group regarding the term "sports" were presented. According to the Table, it was observed that the positive metaphors of the study group regarding the term "sports" were clustered in the sub-groups of assigning values (Assigning values $\mathrm{f}=92, \% 41,81$ ). This situation was confirmed in the expressions of assigning value examples such as "Sports are like my family, I always want them to be next to me" in (f118), "I feel respectable via sports" in (f94) and "Sports are my future" in (f13). In the sub-group of healthy life, it was observed that the students had a 60 frequency distribution (healthy life $\mathrm{f}_{\mathrm{f}=60, \%=27.27}$ ). In this sub-group, it was observed that the participants expressed examples in the group of healthy life such as "Sports are necessary for a healthy life" in (f51), "My breath relaxes when I exercise" in (f8) and "I feel healthy" in (f19).

In the socialization sub-group, it was observed in Table 3 that students had a total frequency of 45 over 6 metaphors (socialization $\mathrm{f}_{\mathrm{f}} 45, \%=20.45$ ). Investigating the sample metaphors in the socialization sub-group, it was observed that expressions related to socialization were presented in samples such as "I get to know new places and new people via sports" in (f187) and "I establish new friendships" in (f41). 
Table 4. Classification of the negative metaphors formed regarding the term "sports" into sub-groups and the frequency and percentage of the students representing those

\begin{tabular}{|c|c|c|c|c|c|c|c|}
\hline \multirow{2}{*}{ Category } & \multirow{2}{*}{ Code } & \multirow{2}{*}{ Metaphor } & \multirow{2}{*}{ Sample Expressions of Students } & \multicolumn{4}{|c|}{$\begin{array}{l}\text { Students representing the } \\
\text { metaphor }\end{array}$} \\
\hline & & & & $\mathrm{f}$ & $\%$ & $\begin{array}{c}\text { Codes } \\
\text { (f) }\end{array}$ & $\begin{array}{c}\text { Total } \\
(\%)\end{array}$ \\
\hline \multirow{5}{*}{ 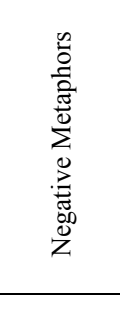 } & 25 & Addiction & $\begin{array}{c}\text { "It formed an addiction in me. I feel like I need training and exercise } \\
\text { every moment" }\end{array}$ & 9 & 4.09 & \multirow{5}{*}{23} & \multirow{5}{*}{10.45} \\
\hline & 26 & Stress & "I get very stressed before every competition" & 6 & 2.72 & & \\
\hline & 27 & $\begin{array}{l}\text { Loss of } \\
\text { Time }\end{array}$ & "I do it because I have to. it is a loss of time for me" & 5 & 2.27 & & \\
\hline & 28 & Poison & "Once you are poisoned. you cannot give it up" & 2 & 0.90 & & \\
\hline & 29 & Darkness & "While exercising. a feeling of being unsuccessful occurs" & 1 & 0.45 & & \\
\hline & & & TOTAL & 23 & 10.45 & 23 & 10.45 \\
\hline
\end{tabular}

In Table 4, the negative metaphors regarding the term "sports" were presented. Accordingly, it was determined that the students expressed samples of negative expressions such as "It formed an addiction in me, I feel like I need training and exercise every moment" in (f19) and "I get very stressed before every competition" in (f4). Of the total population, the number of negative metaphors is 5 while the frequency distribution was 23 (negative metaphor $\mathrm{f}=23, \%=10.45$ ).

\section{Discussion and Results}

This study was conducted with the aim of determining the perceptions of students, who participate in sports organizations in universities as licensed athletes, regarding the term "sports". In the study, it was observed that a majority of the students $(89.54 \%)$ formed positive metaphors regarding the term "sports". The positive metaphors were especially obtained from the sub-groups of assigning values, healthy life and socialization. It was further observed that the negative metaphors of the university students regarding the term "sports" were coded in addiction, stress, failure, loss of time and darkness.

Sometimes, it is difficult to access individuals' ideas regarding certain concepts. This is because individuals may feel a lack of information about certain concepts and may abstain from expressing concepts directly. On such an occasion, metaphors, which is a powerful tool to reveal the mental images of individuals (Saban et al., 2006; Semerci, 2007; Şahin \& Baturay, 2013), can be used. Accordingly, in this study, the perceptions of the university students were attempted to be revealed via metaphors.

By using metaphors in determining perceptions, forming sentences as metaphors within the same lexical area facilitates the determination of perceptions. For example, in the study by Akkaya (2013), it was revealed that Syrian refugees used the metaphors of a mother, a home and a human, which indicated they trusted in Turks and Turkey. Furthermore, using metaphors of Turks and Turkey in a positive association was presented as a result of the study, proving the trust felt towards Turks and Turkey. Additionally, metaphors such as bird, sea, life and breath can be evaluated within the lexical area of the concept of "freedom". In this sense, our study has similarities with the study conducted by Akkaya (2013).

As a result of the study, it was determined that the study group had high levels of positive perception towards the term "sports". In the study conducted by Koç et al. (2015) with $7^{\text {th }}$-grade primary education students, it was noted that positive metaphors regarding the term "sports" were plenty. The results of our study have similarities with the results of the study conducted by Koç et al. (2015).

In the study conducted by Yalçın and Enginer (2012), it was aimed to reveal the perceptions regarding school principals via metaphors. In that study, metaphors were collected into 25 conceptual categories and the results were discussed in the light of the findings obtained. Metaphor studies are powerful tools in terms of directly revealing the perceptions existing in the minds of people regarding any concept. By using metaphors, it was concluded that it was rather important to reveal the perceptions of students, teachers, parents and school administrators regarding school principals in terms of their duties, implementations, behaviors and statements. The findings of our study have parallelisms with the study conducted by Yalçın and Enginer (2012) in terms of methods and findings of research.

According to Morgan, using metaphors is generally personal because it is a type of thinking and viewing which helps us comprehend our world (As cited in Çelikten, 2006, p. 270). Therefore, there can be as many metaphors or 
explanations of metaphors as the number of people who form metaphors. Considering the facts that 220 university students in this study formed 29 metaphors and there were similar expressions of metaphors, it can be interpreted that there is a close and strong differentiation in the perceptions of university students regarding sports. Furthermore, it can be said that all of the metaphors formed by students were about healthy life and assigning values. In terms of sports being an indispensable part of students' lives, forming metaphors is also worthy of attention. Additionally, sportive studies should also be conducted in order to reveal students' perceptions of sports in physical, psychological and social field as well as the cognitive perceptions of students.

As a result of the study, it can be concluded that the term "sports" has a positive place at the perception level for university students. Considering the fact that university youth participate in sports organizations as a recreation activity outside of lesson environment, it was concluded that "sports" had effects on social adaptation and socialization as a result of the study. In this context, it can be thought that universities should allocate more coverage to sports activities besides education practices.

The metaphors obtained as a result of this study can help academics working in tertiary level in the field of physical education and sports, to high school teachers who teach physical education and sports in the processes of education and assessment and evaluation.

\section{References}

Akkaya, A. (2013). Perceptions of Turkish by Syrian Refugees. Ekev Academy Journal, 17(56), 179-190.

Arslan, M. M., \& Bayrakçı, M. (2006). Investigation of Metaphoric Thinking and Learning Approach in terms of Education. Millî Eğitim Dergisi, 171, 100-108.

Aydin, F. (2010). Metaphors of secondary school students about the concept of geography. Educational Sciences in Theory and Practice, 10(3), 1293-1322.

Balc1, A. (1999). Metaphorical Images of School: School Perceptions of Students, Teachers and Parents from four Selected Schools (in Ankara). A Dissertation Submitted in Partial Fulfillment of The Requirements for The Degree of Doctor of Educational Science, METU, Ankara.

Çelikten, M. (2006). Culture and teacher metaphors. Erciyes Üniversitesi Sosyal Bilimler Enstitüsü Dergisi, $1(21), 269-283$.

Cerit, Y. (2008). Opinions of Teachers, Teachers and Managers on Metaphors Related to Teacher Concept. Türk Ë̆itim Bilimleri Dergisi, 6(4), 693-712.

Creswell, J. W. (2013). Qualitative research methods: Qualitative research and research design according to five approaches (Üçüncü baskıdan çev.) (M. Bütün ve S. B. Demir).Siyasal Kitabevi, Ankara

Fenwick, T. (2000). Adventure guides, outfitters, firestarters, and caregivers: Continuing educators' images of identity. Canadian Journal of University Continuing Education, 26(1), 53-77.

Koç, M., Murathan, F., Yetiş, Ü., \& Murathan, T. (2015). Perceptions of 7th grade students on the concept of sports. Journal of Academic Social Research, 3(9), 294-303.

Lakoff, G., \& Johnson, M. (2005). Metaphors of Life, Meaning and Language (Çev: G. Y. Demir). İstanbul: Paradigma Yayınları.

Lipsyte, R. (1975). Sportsworld: An American Dreamland. Quadrangle Books, New York.

Miles, M. B., \& Huberman, A. M. (1994). An Expanded Source Book Qualitative Data Analysis. Thous and Oaks, California: Sage Publications.

Nikitina, L., \& Furuoka F., (2008). “A Language Teacher is Like...”: Examining Malaysian Students' Perceptions of Language Teachers through Metaphor Analysis. Electronic Journal of Foreign Language Teaching, 5(2), 192-205. Retrieved from http://e-flt.nus.edu.sg/v5n22008/nikitina.pdf

Offstein, E. H., \& Neck, C. P. (2003). "From" acing the test" to "touching base": The sports metaphor in the classroom. Business Communication Quarterly, 66(4), 23-35.

Palmatier, R. A., \& Ray, H. L. (1989). Sports talk: A dictionary of sports metaphors. Greenwood Pub Group, Westport. https://doi.org/10.1177/108056990306600403

Saban, A. (2004). Metaphors of Pre-Service Classroom Teachers' Suggestions about 'Teacher' Concept. Turkish Journal of Educational Sciences, 2(2), 131-155.

Saban, A. (2008). School metaphors. Educational Administration in Theory and Practice, 55(55), 459-496. 
Saban, A., Koçbeker, B. N., \& Saban, A. (2006). Examining the perceptions of pre-service teachers about the concept of teacher through metaphor analysis. Educational Sciences in Theory and Practice, 6(2), 461-522.

Şahin, Ş., \& Baturay, M. H. (2013). Evaluation of Perceptions of Secondary School Students about Internet Concept: A Metaphor Analysis Study. Kastamonu Education Journal, 21(1), 177-192.

Semerci, Ç. (2007). A Different View to New Elementary Education Programs with Metaphors on the Concept of Curriculum Development. Cumhuriyet University Journal of Social Sciences, 31(40), 125-140.

Yalçın, M., \& Enginer, A. (2012). Metaphoric Perception of Principals in Primary Schools Journal of Teacher Education and Educators. Journal of Teacher Education and Educators, 1(2), 229-256.

Yıldırım, A., \& Şimşek, H. (2006). Qualitative research methods in the social sciences (6. baskı). Ankara: Seçkin Yayıncılık.

\section{Copyrights}

Copyright for this article is retained by the author(s), with first publication rights granted to the journal.

This is an open-access article distributed under the terms and conditions of the Creative Commons Attribution license (http://creativecommons.org/licenses/by/4.0/). 